\title{
ИНГИБИТОРЫ СИНТЕЗА АТФ \\ НА ОСНОВЕ 2,4-ДИНИТРОФЕНОЛА
}

П.В. Островерхов ${ }^{1}$, К.Ю. Власова ${ }^{2,3}$, Д.Г. Веденяпина', А. Радованович', И.А. Лобанов', М.А. Абакумов ${ }^{3,4}$

${ }^{1}$ МИРЭА - Российский технологический университет, Институт тонких химических технологий им. М.В. Ломоносова, 119571, Россия, Москва, пр-кт Вернадского, 86.

${ }^{2}$ Химический факультет МГУ имени М.В. Ломоносова, Москва, Россия.

${ }^{3}$ Российский Национальный Исследовательский Медицинский Университет им. Н.И. Пирогова, Москва, Россия.

${ }^{4}$ Национальный Исследовательский Технологический Университет «МИСиС», Москва, Россия.

DOI: 10.19163/MedChemRussia2021-2021-547

E-mail:mrp_ost@mail.ru

Сахарный диабет второго типа (СД-2) и неалкогольная жировая болезнь печени (НАЖБП) являются одними из самых актуальных проблем современной медицины [1]. По последним литературным данным не существует разрешенных для клинического применения препаратов для лечения НАЖБП как самостоятельного заболевания, так и в сочетании с СД-2. Одной из перспективных молекул, которая может быть эффективна при лечении НАБЖП и СД-2, является 2,4-динитрофенол, изменяющий активность митохондрий. Для того чтобы убрать ранее установленные побочные эффекты от употребления 2,4-динитрофенола, возникла задача в разработке эффективной формуляции данной молекулы для направленной доставки в печень [1].

В исследовании были проведены разработка и оптимизация методов синтеза и выделения ряда производных 2,4-динитрофенола. Были получены алкилпроизводные 2,4-динитрофенола с различной длиной цепи и степени разветвленности заместителя, а также полициклические ароматические производные аналоги 2,4-динитрофенола на основе 2-бензилфенола и нафтола-1. Целевые соединения были получены в результате прямого нитрования различных фенолов. Также были получены нано-структурированные формы полученных соединений и исследована их способность ингибировать синтез АТФ при помощи люциферин-люциферазного метода.

Таким образом, нами были получены и успешно выделены липофильные производные 2,4-динитрофенола с различной длиной цепи и степени разветвленности заместителей для таргетной доставки в печень в составе липосомального препарата как перспективного средства лечения НАЖБП и СД-2.

Работа поддержана грантом Российского научного фонда № 20-73-00333.

\section{Литература}

[1] Tanase DM, Gosav EM, Costea CF, et al. The Intricate Relationship between Type 2 Diabetes Mellitus (T2DM), Insulin Resistance (IR), and Nonalcoholic Fatty Liver Disease (NAFLD). J. Diabetes Res. 2020 